\title{
Effects of climate changes on distribution of Eremanthus erythropappus and $E$. incanus (Asteraceae) in Brazil
}

\author{
Lucas Fernandes Rocha ${ }^{1}$ - Isaias Emilio Paulino do Carmo ${ }^{2}$. \\ Joema Souza Rodrigues Póvoa ${ }^{1}$ Dulcinéia de Carvalho ${ }^{1}$
}

Received: 27 June 2018/Accepted: 13 September 2018/Published online: 10 May 2019

(C) The Author(s) 2019

\begin{abstract}
Phylogeographic patterns of endemic species are critical keys to understand its adaptation to future climate change. Herein, based on chloroplast DNA, we analyzed the genetic diversity of two endemic and endangered tree species from the Brazilian savanna and Atlantic forest (Eremanthus erythropappus and Eremanthus incanus). We also applied the climate-based ecological niche modeling (ENM) to evaluate the impact of the Quaternary climate (last glacial maximum $\sim 21 \mathrm{kyr}$ BP (thousand years before present) and Mid-Holocene $\sim 6 \mathrm{kyr} \mathrm{BP}$ ) on the current haplotype distribution. Moreover, we modeled the potential effect of future climate change on the species distribution in 2070 for the most optimistic and pessimistic scenarios. One primer/enzyme combination (SFM/HinfI) revealed polymorphism with very low haplotype diversity, showing only three different haplotypes. The haplotype 1 has very low frequency and it was classified as the oldest,
\end{abstract}

Project funding: This study was financed in part by the Coordenação de Aperfeiçoamento de Pessoal de Nível Superior (CAPES)-Finance Code 001.

The online version is available at http://www.springerlink.com.

Corresponding editor: Yu Lei.

Electronic supplementary material The online version of this article (https://doi.org/10.1007/s11676-019-00968-z) contains supplementary material, which is available to authorized users.

Lucas Fernandes Rocha

lucasrochamg@gmail.com

1 Departamento de Ciências Florestais, Universidade Federal de Lavras, Lavras, MG CEP 37200-000, Brazil

2 Institute of Biosystems Engineering, Poznan University of Life Sciences, Wojska Polskiego 50, 60-637 Poznan, Poland diverging from six mutations from the haplotypes 2 and 3. The E. erythropappus populations are structured and differ genetically according to the areas of occurrence. In general, the populations located in the north region are genetically different from those located in the center-south. No genetic structuring was observed for E. incanus. The ENM revealed a large distribution during the past and a severe decrease in geographic distribution of E. erythropappus and $E$. incanus from the LGM until present and predicts a drastic decline in suitable areas in the future. This reduction may homogenize the genetic diversity and compromise a relevant role of these species on infiltration of groundwater.

Keywords Ecological niche modeling - Genetic diversity · Climate change $\cdot$ Chloroplast DNA

\section{Introduction}

Future climate change will create several impacts on biodiversity (Ravenscroft et al. 2015). A recent meta-analysis demonstrated that the negative impacts of habitat loss and fragmentation have been disproportionately severe in areas with high temperatures during the warmest month and declining rainfall (Zuber and Villamil 2016). Several studies addressing the impacts of climate change has been developed mainly focusing the loss of species diversity. Nevertheless, a few studies have evaluated the influence of climate on the genetic characteristics of populations.

Past bioclimatic scenarios models have shown that current species distribution follows a pattern of gene sharing since the Late Glacial Period (Collevatti et al. 2013). The cyclical climatic changes during the Quaternary period had a complex impact on the population dynamics 
of tropical, Neosavanna species, consequently influencing their current species distribution and genetic diversity (Collevatti et al. 2015). While some species have shown resilience facing new climatic conditions (Kremer et al. 2012), future climate change will influence the species' genetic diversity and adaptation to new environmental conditions (Lima et al. 2017).

The Brazilian savanna and the Atlantic forest are currently considered as global biodiversity hotspots in reason of the high level of susceptibility and the presence of endemic species (Myers et al. 2000). Additionally, Brazil's savanna is also classified as one of the most threatened savanna ecosystems on Earth (Gries et al. 2012) and the Atlantic forest biome is known as the hottest biodiversity hotspot, as a result of its high endemism of plants and vertebrates (Myers et al. 2000). Moreover, Brazilian high altitudinal grasslands have enormous numbers of endemism of plants, with restricted to isolated patches (Iganci et al. 2011). Besides, relevant ecological concerns and the current deforestation pressure faced by these ecosystems make them relevant biodiversity hotspots for conservation (Tse-ring et al. 2010).

The genus Eremanthus is composed of 22 tree and shrub species restricted to the arid Cerrado in the Central Plateau of Brazil (Loeuille et al. 2012). E. erythropappus (DC.) MacLeish occurs generally at altitudes of $700-2400 \mathrm{~m}$ as colonies within secondary forest, mainly in seasonally dry tropical forest of the coastal range and it is also found through the Brazilian savanna and the Atlantic forest. In these sites, the species has a key role in environmental services mainly as a source of water. Meanwhile, E. incanus (Less.) Less is particularly common in Minas Gerais State, at elevations from 800 to $1850 \mathrm{~m}$ in savanna, secondary forest, and semi-arid region. Possible hybrids of these two species have been found in southern Minas Gerais (MacLeish 1987).

The exploitation of these species dates from the Brazilian colonial period. At that time, its wood began to be used as fences material due to the long-standing durability, caused by the high concentration of essential oils. Because of its composition, E. erythropappus has been used for the extraction of alfa-bisobolol, an alcohol distilled from the essential oil extracted from its wood that is in high demand by pharmaceutical industries. However, the alfa-bisobolol extracted from the wood of E. incanus has lower quantity and quality; therefore, its main commercial use is the production of logs, largely for fence construction (Scolforo et al. 2012).

Several studies have analyzed the phenology and reproductive biology (Vieira et al. 2012), genetic patterns (Barreira et al. 2006; Silva et al. 2007; Pádua et al. 2016) and in vitro propagation (Miranda et al. 2016) of Eremanthus species. The studies of its phylogeographic patterns and climatic variation responses are important for understanding historical patterns of seed dispersal, recolonization routes, genetic diversity distribution and species refugia.

Understanding the association between phylogeographical modeling and molecular data is an important method to better comprehend species' spatial dynamics (Collevatti et al. 2012). Besides, phylogeography examines the relationships between genetics and geographical species distribution and it is based on the spatial distribution of gene genealogies (Avise et al. 1987). The variability of conserved cytoplasmic genomes with uniparental inheritance, such as chloroplast for plants (cpDNA), results in low levels of mutation and no recombination making this marker suitable for phylogeographic studies (Avise 1994; Birky and Walsh 1988).

In this study, we evaluated the effects of climate change on the potential geographical distribution of E. erythropappus and E. incanus. We used chloroplast-specific markers to access the level and distribution of genetic diversity of E. erythropappus and E. incanus throughout Minas Gerais State, Brazil. We also used ecological niche modelling (ENM) to assess past and present distribution of these species and evaluate the possible impacts of future climate change on the species distribution for the year 2070. Our aim is to infer the spatial-temporal dynamics of these species, as suggested by predictions of past, current, and future species distribution.

\section{Materials and methods}

\section{Sampling locations and plant material}

Leaf samples were collected from 141 individuals in nine natural populations of E. erythropappus and 25 individuals in four natural populations of $E$. incanus, in three different regions of Minas Gerais State, Brazil. The sample populations include: Antônio Dias (AD), two populations in Francisco Sá (FS), Joaíma (JO), two populations in Rio Pardo de Minas (RP), Morro do Pilar (MP), Aiuruoca (AI), Baependi (BA), Carrancas (CA), two populations in Lavras (LV), and São Tomé das Letras (ST). Site coordinates and sample size per site are given in Table 1. Sampled individuals were at least $50 \mathrm{~m}$ apart and each individual was georeferenced. Voucher specimens were deposited in the ESAL herbarium of the Federal University of Lavras (UFLA), Brazil.

\section{PCR amplification}

We tested 15 primers in this study: trnH-psbA, $r p l 20$ $r p s 12$, $t r n \mathrm{~S}-t r n \mathrm{G}, p s b \mathrm{~B}-p s b \mathrm{~F}$ (Hamilton 1999), trnQ-trnS, 
Table 1 Location and sample size of the Eremanthus erythropappus (EE) and $E$. incanus (EI) populations

\begin{tabular}{lllll}
\hline Population & Latitude & Longitude & Region & Species (sample size) \\
\hline Antônio Dias (AD) & $19^{\circ} 31^{\prime} 45.08^{\prime \prime} \mathrm{S}$ & $42^{\circ} 49^{\prime} 34.43^{\prime \prime} \mathrm{W}$ & North & EE (15) \\
Francisco Sá (FS) & $16^{\circ} 28^{\prime} 25.6^{\prime \prime} \mathrm{S}$ & $43^{\circ} 24^{\prime} 43.2^{\prime \prime} \mathrm{W}$ & North & EE (12); EI (4) \\
Joaíma (JO) & $16^{\circ} 38^{\prime} 30.91^{\prime \prime} \mathrm{S}$ & $40^{\circ} 59^{\prime} 47.89^{\prime \prime} \mathrm{W}$ & North & EE (6) \\
Rio Pardo de Minas (RP) & $15^{\circ} 39^{\prime} 0.95^{\prime \prime} \mathrm{S}$ & $42^{\circ} 33^{\prime} 54.80^{\prime \prime} \mathrm{W}$ & North & EE (3); EI (6) \\
Morro do Pilar (MP) & $19^{\circ} 12^{\prime} 15.0^{\prime \prime} \mathrm{S}$ & $43^{\circ} 23^{\prime} 15.0^{\prime \prime} \mathrm{W}$ & Center & EE (15) \\
Airuoca (AI) & $21^{\circ} 59^{\prime} 45.63^{\prime \prime} \mathrm{S}$ & $44^{\circ} 36^{\prime} 4.85^{\prime \prime} \mathrm{W}$ & South & EE (15) \\
Baependi (BA) & $21^{\circ} 58^{\prime} 31.3^{\prime \prime} \mathrm{S}$ & $44^{\circ} 46^{\prime} 09.4^{\prime \prime} \mathrm{W}$ & South & EE (30) \\
Carrancas (CA) & $21^{\circ} 27^{\prime} 01.5^{\prime \prime} \mathrm{S}$ & $44^{\circ} 39^{\prime} 33.8^{\prime \prime} \mathrm{W}$ & South & EE (15) \\
Lavras (LV) & $21^{\circ} 19^{\prime} 50.36^{\prime \prime} \mathrm{S}$ & $44^{\circ} 57^{\prime} 57.49^{\prime \prime} \mathrm{W}$ & South & EE (15); EI (15) \\
São Tomé das Letras (ST) & $21^{\circ} 42^{\prime} 13.1^{\prime \prime} \mathrm{S}$ & $45^{\circ} 59^{\prime} 16.2^{\prime \prime} \mathrm{W}$ & South & EI (15) \\
\hline
\end{tabular}

$\operatorname{trnS}$-trnR, trn $\mathrm{T}-p s b \mathrm{C}, \operatorname{trn\mathrm {F}}-t r n \mathrm{~V}, \operatorname{trn} \mathrm{V}-\mathrm{rbcL}$ (DumolinLapégue et al. 1997), trnL-C-trnL-D, trnD-trnT, $p s b \mathrm{C}-$ $\operatorname{trnS}, \operatorname{trnS}-t^{\prime n f} \mathrm{f}_{\mathrm{M}}, \operatorname{trnS}-\operatorname{trn\mathrm {T}}$ (Demesure et al. 1995), and trnT-trnF (Taberlet et al. 1991). The PCR amplifications were carried out in a total volume of $25 \mu \mathrm{L}$ containing approximately $3 \mathrm{ng}$ of total DNA, $10 \mathrm{mM}$ Tris $\mathrm{pH} 8.0$, $50 \mathrm{mM} \mathrm{KCl}, 2.5 \mu \mathrm{g}$ of BSA, $200 \mu \mathrm{M}$ of each dNTP, $2 \mathrm{mM}$ of $\mathrm{MgCl}_{2}, 2 \mathrm{U}$ of Taq polymerase, and $0.2 \mu \mathrm{M}$ of each primer. The thermal cycling program was: one cycle of 4 min at $94{ }^{\circ} \mathrm{C}$; 30 cycles of $45 \mathrm{~s}$ at $94{ }^{\circ} \mathrm{C}, 45 \mathrm{~s}$ at $56{ }^{\circ} \mathrm{C}$, and $3 \mathrm{~min}$ at $72^{\circ} \mathrm{C}$; and a final extension of $7 \mathrm{~min}$ at $72{ }^{\circ} \mathrm{C}$. For primers $t r n \mathrm{H}-p s b \mathrm{~A}, 20-12$, and $p s b \mathrm{~B}-p s b \mathrm{~F}$ the amount of dNTPs was reduced to $100 \mu \mathrm{M}$ of each and the cycling program used was: one cycle of $5 \mathrm{~min}$ at $96{ }^{\circ} \mathrm{C} ; 35$ cycles of $45 \mathrm{~s}$ at $96{ }^{\circ} \mathrm{C}, 1 \mathrm{~min}$ at $53{ }^{\circ} \mathrm{C}$, and $30 \mathrm{~s}$ at $72{ }^{\circ} \mathrm{C}$; and a final extension of $7 \mathrm{~min}$ at $72^{\circ} \mathrm{C}$.

\section{RFLP analysis}

The PCR products $(5 \mu \mathrm{L})$ were digested for $1 \mathrm{~h}$ using the HinfI, HindIII, HaeIII, MseI, TaqI, AluI, EcoRI, and BamHI restriction enzymes. Each restriction was undertaken in a total volume of $10 \mu \mathrm{L}$ at the temperatures recommended by the enzyme manufacturer (Gibco-BRL, Brazil). The digestion products were separated on $3 \%$ agarose gels for $2 \mathrm{~h}$ at $60 \mathrm{~V}$ and the gels were stained with ethidium bromide and photographed under UV light. The replicability for each PCR and enzyme/PCR product combination was assessed by replicating each reaction.

\section{Genetic analysis}

The total genetic diversity $\left(H_{\mathrm{T}}\right.$ and $\left.V_{\mathrm{T}}\right)$, intrapopulation genetic diversity $\left(H_{\mathrm{S}}\right.$ and $\left.V_{\mathrm{S}}\right)$, and the differentiation indexes $\left(G_{\mathrm{ST}}\right.$ and $\left.N_{\mathrm{ST}}\right)$ were calculated based on alleles frequencies and the distance between haplotypes for nonordered and ordered alleles, respectively, using the software HAPLONST (Pons and Petit 1996). The same program was used to estimate v-type parameters. A minimum spanning tree (Excoffier and Smouse 1994) and AMOVA were calculated using ARLEQUIN 3.11 (Excoffier et al. 2007). The contribution of each population to total diversity and total allelic richness (CT) was estimated using the software CONTRIB (Petit et al. 1998). This contribution is explained by two factors: the diversity of the population (CS); and the differentiation of the remaining populations (CD).

\section{Species distribution modeling}

The database consisted of a set of 19 raster files of bioclimatic variables and altitude were extracted from WorldClim (www.worldclim.org/bioclim) (Hijmans et al. 2005). We used 341 herbarium occurrence locations of $E$. erythropappus (198) and E. incanus (143), downloaded from the Global Biodiversity Information Facility (GBIF 2018). The modeling was performed using the maximum entropy model software, MaxEnt 3.4 (Phillips 2017). According to Hernandez et al. (2006), this model has a high level of accuracy for species modeling and it is less sensitive to small sample sizes (Wisz et al. 2008). We used a spatial resolution of 2.5 arc-seconds $(5 \mathrm{~km}$ at the equator). The database was divided in $25 \%$ for validation and $75 \%$ for training and to train the five periods under study: Last Glacial Maximum (LGM), about 22 kyr BP; Mid-Holocene, about $6 \mathrm{kyr}$ BP; current conditions, between 1960 and 1990; RCP 2.6 and RCP 8.5 for the year 2070. RCP 2.6 represents the most optimistic scenario, with global temperature increase varying from 0.3 to $1.7^{\circ} \mathrm{C}$ by the year 2100 , and RCP 8.5 represents the most pessimistic scenario, with an increase in temperature varying from 1.4 to $4.8^{\circ} \mathrm{C}$ by 2100 (Stocker et al. 2013).

We tested the Community Climate System Model (CCSM 4.0) (CESM 2017) to simulate the earth's climate conditions. This model has been widely used to understand past conditions and project the effects of future climate change (Gent 2011). We used 20 replicate cross validation runs, in which all occurrence data were randomly split into 
a number of equal-sized groups (Phillips and Dudík 2008). In addition, we used a maximum of 2000 iterations and convergence threshold of 0.001 (Vieira et al. 2015).

The model efficiency was tested using the area under the ROC curve (AUC) generated by the MaxEnt model. The model values vary from 0 to 1 , with values close to 1 showing a high efficiency and it is often used on validation of models (Fielding and Bell 1997; Elith et al. 2006; Phillips 2017).

\section{Results}

\section{Genetic analyses}

An initial screening of 15 pairs of universal chloroplast primers with eight restriction enzymes revealed easily scorable variation for only one primer-enzyme combination (SFM/HinfI) which was used throughout the study. Altogether, this combination revealed one restriction site mutation and two insertion/deletion mutations, constituting three haplotypes (Fig. S1). The minimum spanning tree showed that haplotype 1 is the oldest and diverges from six mutations and haplotypes 2 and 3 are divergent from two mutations (Fig. 1). Haplotype 1 appears in very low frequency in both species (1.6\% in E. erythropappus and $2.5 \%$ in E. incanus). We found that haplotype 3 was the most common (95.2\%) in E. erythropappus and haplotype 2 was the most common for E. incanus (90\%). We did not find haplotype 2 in E. erythropappus populations located in the center-south region, but it appears with a frequency of $11 \%$ in the northern populations (Fig. S2).

Populations RP, JO, and FS contributed most to the total diversity (CS) in E. erythropappus (37\%, $13 \%$ and $11 \%$ ), and population FS (42\%) contributed most for E. incanus due to the presence of haplotypes 2 and 3 . The contribution of differentiation (CD) in all populations was very low (2\% in MP, BA, CA and AI populations for E. erythropappus and $8 \%$ in ST population for E. incanus) which is probably due to the restricted number of haplotypes found for these species (Fig. S3). The predominance of only one haplotype in all populations of both species generated low estimated

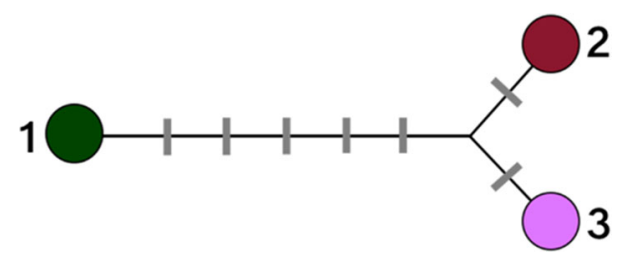

Fig. 1 Minimum spanning network for the three haplotypes obtained from Eremanthus erythropappus and E. incanus. The observed traits refer to the number of mutations observed among haplotypes. The numbers 1,2 , and 3 refer to the haplotypes diversities for both unordered and ordered alleles (Table 2). No genetic substructure was found for these species and regions $\left(G_{\mathrm{ST}}=0.611\right.$ and $\left.N_{\mathrm{ST}}=0.541\right)$, indicating that the identified genetic differentiation is not due to the distribution of haplotypes (Table S1).

For E. erythropappus, the total genetic diversity $\left(H_{\mathrm{T}}\right.$ and $V_{\mathrm{T}}$ ) were both equal to 0.167 , and the intrapopulational genetic diversity $\left(H_{\mathrm{S}}\right.$ and $\left.V_{\mathrm{S}}\right)$ were 0.174 and 0.117 , respectively. In general, we found a higher variability $\left(V_{\mathrm{S}}=0.350\right.$ and $\left.V_{\mathrm{T}}=0.312\right)$ on the northern populations when compared with the southern ones $\left(V_{\mathrm{S}}\right.$ and $V_{\mathrm{T}}$ $=0,027)$. For $E$. incanus, $H_{\mathrm{T}}$ and $V_{\mathrm{T}}$ were equal to 0.210 and 0.209 , and $H_{\mathrm{S}}$ and $V_{\mathrm{S}}$ equal to 0.220 and 0.217 , respectively (Table S1). We confirmed this result with AMOVA, which shows that most of the genetic variation occurs between species (Table 2). Despite the low variation between populations within species, the genetic differentiation was significant. The results from AMOVA showed that populations of E. erythropappus are structured regionally and most of the genetic variation occurs within populations $(86 \%)$. This result was confirmed by the Mantel test made between the pairs of populations which indicated a positive and significant correlation between distance geography and genetic distance $(r=0.33$, $p=0.04)$. We found no genetic variation among regions for $E$. incanus, demonstrating a high genetic variation within populations $(97.7 \%)$. This result was confirmed by the Mantel test, which indicated negative but not significant correlation between populations $(r=-0.36$, $p=0.91)$.

\section{Species distribution modeling}

From the initial 20 variables extracted from WorldClim, 10 were chosen as they had the greatest influence on the MaxEnt model (Table 3). The ENM was successful based on the satisfactory AUC values for both species: E. erythropappus-LGM model, AUC $=0.982$; Holocene model, AUC $=0.982 ;$ Current model, $\mathrm{AUC}=0.983 ; \mathrm{RCP} 2.6$ model for 2070, AUC $=0.982$; RCP 8.5 model for 2070, AUC $=0.982 ;$ E. incanus $-\mathrm{LGM}$ model, $\mathrm{AUC}=0.980$; Holocene model, AUC $=0.980 ;$ Current model, AUC $=$ $0.980 ;$ RCP 2.6 model, $\mathrm{AUC}=0.978 ; \mathrm{RCP} 8.5$ model, $\mathrm{AUC}=0.979$.

The ENM performed adequately for all five study periods (Last Glacial Maximum; Mid-Holocene; current day; RCP 2.6; and RCP 8.5). The environmental variables that most influenced the MaxEnt model were altitude, mean temperature of coldest quarter and precipitation seasonality (Table 3). We observed a gradual reduction in suitable area for species distribution over time (Figs. 3c, d, $4 \mathrm{c}$ and d). The main difference was from the LGM climate scenario, the oldest period, where the species distribution was 
Table 2 Hierarchical analysis of molecular variance for populations of Eremanthus erythropappus (EE) and E. incanus (EI)

\begin{tabular}{|c|c|c|c|c|c|c|}
\hline Populations & Hierarchical level & DF & Sum of squares & $\%$ of variation & (1-statistics & $P$ value \\
\hline \multirow[t]{3}{*}{ Species } & Between species & 1 & 23.123 & 86.71 & $\Phi_{\mathrm{CT}}=0.87$ & $<0.001$ \\
\hline & Between population among species & 11 & 1.003 & 0.66 & $\Phi_{\mathrm{ST}}=0.05$ & $<0.001$ \\
\hline & Within populations & 153 & 8.450 & 12.62 & $\Phi_{\mathrm{SC}}=0.87$ & - \\
\hline \multirow[t]{3}{*}{ EE } & Between regions & 1 & 0.372 & 12.40 & $\Phi_{\mathrm{CT}}=0.12$ & $<0.05$ \\
\hline & Between populations among region & 7 & 0.372 & 1.51 & $\Phi_{\mathrm{ST}}=0.14$ & - \\
\hline & Within populations & 117 & 5.033 & 86.09 & $\Phi_{\mathrm{SC}}=0.02$ & $<0.05$ \\
\hline \multirow[t]{3}{*}{ EI } & Between regions & 1 & 0.008 & 0 & $\Phi_{\mathrm{CT}}=-0.08$ & - \\
\hline & Between populations among region & 2 & 0.250 & 3.35 & $\Phi_{\mathrm{ST}}=-0.05$ & - \\
\hline & Within populations & 36 & 3.417 & 97.7 & $\Phi_{\mathrm{SC}}=0.03$ & - \\
\hline
\end{tabular}

Table 3 Contribution of environmental variables used in ecological niche modelling (ENM)

\begin{tabular}{llllll}
\hline Variable & Description & PCEE $^{\mathrm{a}}$ & PCEI $^{\mathrm{b}}$ & PIEE $^{\mathrm{a}}$ & PIEI $^{\mathrm{b}}$ \\
\hline Alt & Altitude & 24.2 & 0.6 & 44.2 & 0.5 \\
Bio 11 & Mean temperature of coldest quarter & 31.5 & 0 & 14.8 & 1 \\
Bio 15 & Precipitation seasonality & 12.5 & 8 & 5.4 & 2.7 \\
Bio 01 & Annual mean temperature & 5.5 & 0.3 & 5.8 & 4 \\
Bio 4 & Temperature seasonality & 4.1 & 13.3 & 2.8 & 12.7 \\
Bio 18 & Precipitation of warmest quarter & 3 & 1.2 & 3.1 & 4.1 \\
Bio 5 & Max temperature of warmest month & 2.7 & 2.3 & 5 & 2.1 \\
Bio 09 & Mean temperature of driest quarter & 2.6 & 1.1 & 1.7 & 1 \\
Bio 6 & Min temperature of coldest month & 2 & 0.3 & 0.7 & 0.1 \\
Bio 10 & Mean temperature of warmest quarter & 1.8 & 0 & 2.3 & 5.5 \\
Bio 8 & Mean temperature of wettest quarter & 0.9 & 5.6 & 1.3 & 3.5 \\
\hline
\end{tabular}

${ }^{a}$ Percent contribution (PCEE) and permutation (PIEE) importance for Eremanthus erythropappus, respectively

${ }^{\mathrm{b}}$ Percent contribution (PCEI) and permutation importance (PIEI) for Eremanthus incanus, respectively significantly wider in comparison to present day with a remarkable reduction in suitable area for both future scenarios.

Based on the ENM for current conditions, we found that the areas of greatest suitability for both species are located in the mid-west, northeast, and southeast regions of Brazil, mainly in Minas Gerais State (Fig. 2). According to Camolesi (2007), the area of E. erythropappus occurrence covers 457 municipalities in Minas Gerais, which corresponds to $34.38 \%$ of the State's area. This species also occurs throughout the southeastern part of the Brazilian Central Plateau, Brazilian coast, Cerrado and rupestrian fields in the Federal District, and the States of Goiás, Espírito Santo, São Paulo, and Rio de Janeiro, Brazil (Macleish 1987; Loeuille et al. 2012). On the other hand, while E. incanus occurs naturally in montane grasslands in Bahia, Espírito Santo, Rio de Janeiro, and São Paulo, the species occurs abundantly in Minas Gerais State, forming large aggregates in the savanna and highlands (Araújo 1944).

\section{Discussion}

\section{Haplotype}

Quaternary climatic fluctuations may have played an important role in shaping haplotype distribution for both $E$. erythropappus and E. incanus, which show similar patterns of phylogeographic distribution and respond similarly to the effects of climate change over time. Based on our analyses, the most intense haplotype diversification and gene flow probably occurred during the last glacial period when both species were distributed over a vast area in South America. This wide dispersal may be responsible for the occasional presence of the same haplotype in both species. The ENM predicted a reduction in suitable area during the Mid-Holocene and consequently a decrease in gene flow between populations for E. erythropappus and $E$. incanus. Additionally, ENM predicted an even greater 


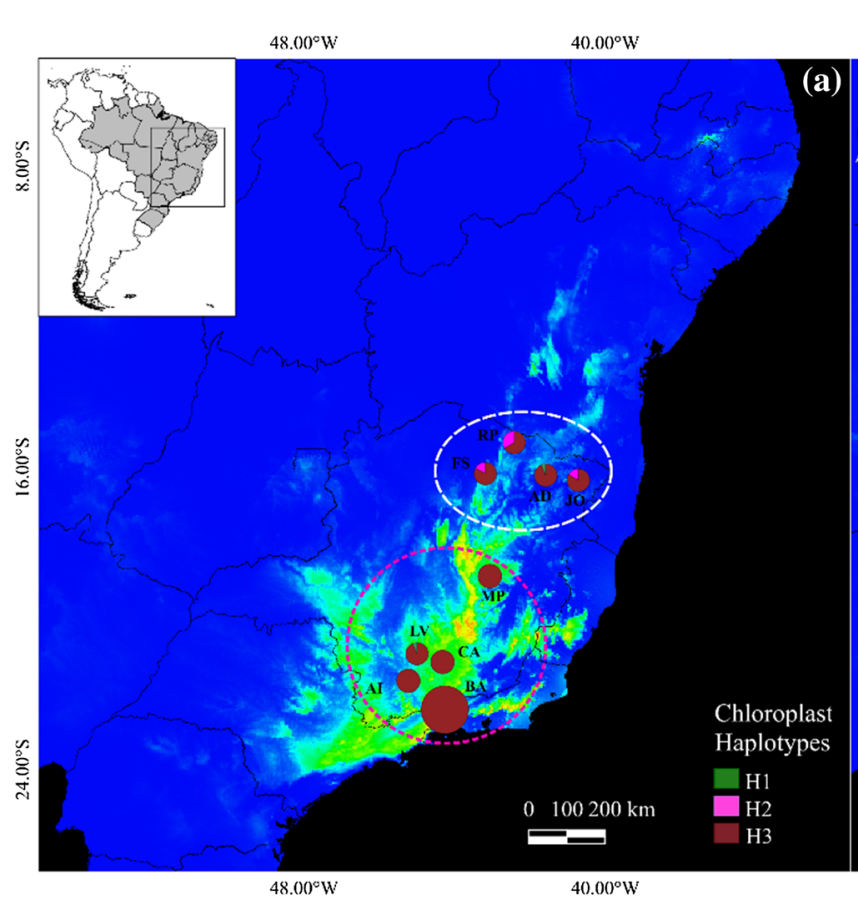

Fig. 2 Geographical distribution of haplotypes and current distribution for (a) Eremanthus erythropappus and (b) Eremanthus incanus. Colors indicate different haplotypes according to the legend. The

reduction in suitable areas for the species for both studied future scenarios.

\section{Genetic analyses}

E. erythropappus and E. incanus populations were characterized by low cpDNA variation and overall diversity and no population differentiation. The results for E. erythropappus showed contrasting patterns to those reported in previous studies using nuclear markers, such as isozymes, RAPD and ISSR; these studies showed high population diversity and overall diversity and significant differentiation between populations (Estopa et al. 2006; Moura 2005; Pádua et al. 2016) probably due the higher mutation rate of those markers than cpDNA (Provan et al. 1999; Rawat et al. 2014). Unlike the cytoplasmic genome, the chloroplast genome is clonal, or inherited maternally, and historical events, such as glaciation and climatic change, have a greater impact on its variation over geological time (Avise 1994; Avise et al. 1987).

The absence of population differentiation based on cpDNA markers for these species is probably due to their wide distribution during the LGM. Meanwhile, recent fragmentation and exploitation has led to population divergence as observed in studies using other molecular markers. The divergence between haplotypes 2 and 3 could have occurred alongside the separation of E. erythropappus and E. incanus into different species or they could $48.00^{\circ} \mathrm{W}$

$40.00^{\circ} \mathrm{W}$

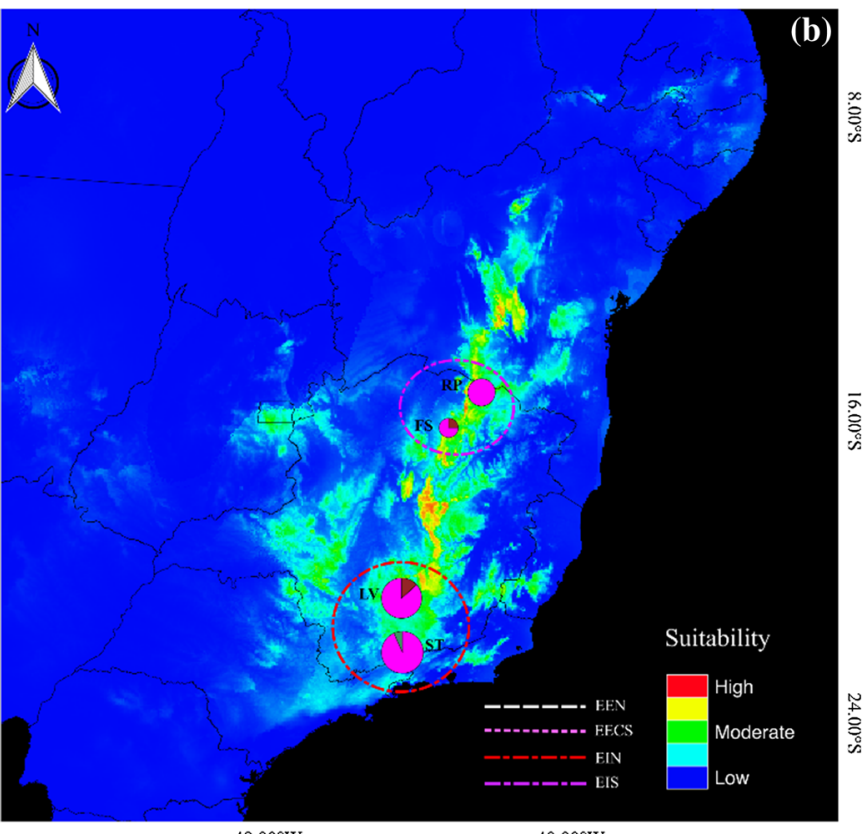

$48.00^{\circ} \mathrm{W}$

$40.00^{\circ} \mathrm{W}$

circle size represents the sample size in each population and circle sections represent the haplotype frequency in each sampled population

represent older polymorphisms, with each haplotype being initially only partly associated with the species. These issues can be clarified with an increase in available cpDNA markers (e.g., by sequencing non-coding regions of the chloroplast genome) and by analyzing a larger sample of populations, species, and locations. With such data, we can better understand the taxonomic and geographical distribution of cpDNA variation for these species and their past evolutionary dynamics.

Haplotype 1 was found in only one E. erythropappus individual from the LV and AD populations, located in the southern and northern regions of Minas Gerais, respectively. Moreover, haplotype 2 was found in only three of the four E. erythropappus populations in the northern region of the state (PR, FS, and JO). Similarly, haplotype 1 was rare for the E. incanus populations, and only identified in one individual from the population of São Tomé das Letras (ST). In general, we observed a lower number of haplotypes for the populations from the central-south (EECS) and southern (EIS) regions for both species.

Cloutier et al. (2005) studying 11 different populations of Carapa guianensis using chloroplast DNA variation, found low intrapopulational diversity for $\left(H_{\mathrm{S}}\right.$ and $V_{\mathrm{S} \text { - }}$ $=0.02)$ and high values of total diversity $\left(H_{\mathrm{T}}=0.82\right.$ and $\left.V_{\mathrm{T}}=0.73\right)$, and a population differentiation value $\left(N_{\mathrm{ST}}\right)$ equal to 0.97. On the other hand, Schlögl et al. (2007) studying the genetic diversity of Araucaria angustifolia, also using cpDNA markers, found values of $H_{\mathrm{S}}$ and $H_{\mathrm{T}}$ 
equal to 0.441 and 0.612 respectively, and a low $\mathrm{N}_{\mathrm{ST}}$ value (0.280). In our study, the low percentage of total diversity observed for E. erythropappus and E. incanus may be related to the small number of haplotypes. The populations with distinct haplotypes should be used as reference areas for ex situ conservation when moving individuals between areas or transplanting them to a new site (Chen et al. 2015).

\section{Ecological niche modeling}

The current distribution and genetic diversity of plants are the result of climatic events, such as the Pleistocene period of glaciation (Abbott and Brochmann 2003; Comes and Kadereit 1998; Hewitt 2000; Newton et al. 1999). The changes that occurred during the glacial period contributed to the contemporary spatial distribution of species through extinction, colonization, dispersals, and isolation (Abbott and Comes 2004; Newton et al. 1999; Lexer and Widmer 2001).

During the last glacial period, the Neotropical environment was both cooler and drier than current climatic conditions. In this environment, the vegetation, such as the seasonally dry tropical forest and the Cerrado, would have reflected those climatic conditions (Pennington et al. 2000). Prado and Gibbs (1993) concluded that fragmentary and mostly disconnected species distribution patterns of dry tropical forest are remnants of a once extensive and largely contiguous seasonal woodland formation that may have reached its maximum extension during a dry-cool period between 18 and $12 \mathrm{kyr} \mathrm{BP,} \mathrm{coinciding} \mathrm{with} \mathrm{the} \mathrm{contraction}$ of the humid forest.

Paleontological evidence from Águas Emendadas, Brazil, dated to the period between 26 and $21.5 \mathrm{kyr} \mathrm{BP}$, shows that the Cerrado biome was mainly characterized by abundant vegetation of grass, savanna, and gallery forests (Barberi et al. 2000) and dominated by Poaceae, Borreria, Cyperaceae, and Asteraceae species (Behling and Hooghiemstra 2001). Surprisingly, the currently occurrence of E. erythropappus and E. incanus is essentially situated in open, high-elevation, and grassland areas and it is restricted to either elevation over $1000 \mathrm{~m}$ or higher latitudes (Mayle et al. 2009).

We found a similar distribution pattern for E. erythropappus and E. incanus for past and current climatic conditions, thus reinforcing these theories for the LGM period $(\sim 21 \mathrm{kyr}$ BP). We found an intense distribution for both species, mainly in the northeast and southeast of Brazil, which largely represents the current Cerrado and some parts of the Caatinga biome (Figs. 3a and 4a). Additionally, the altitudes of occurrence of the studied species are mainly around $1000 \mathrm{~m}$ (Lorenzi 1992). In fact, this pattern of wide distribution for both species in the past may be responsible for the sharing of haplotypes between individuals of the northern (EEN) and southern regions (EECS), as supported by our genetic analyses.

Between 10 and $20 \mathrm{kyr}$ BP, the area occupied by tropical rainforest in South America retreated as a result of climate change and previously continuous populations suffered a reduction in size and likely experienced genetic isolation among distant populations (De-Granville 1988; Prance 1973, 1982). For these species, the loss of genetic diversity within populations and the increase in spatial genetic structure are expected to produce a bottleneck effect (Nei et al. 1975). Our results for ENM may suggest a similar pattern of a significant reduction in species distribution areas for the Mid-Holocene (Figs. $3 b$ and $4 b$ ) and for the current conditions (Fig. 2a and b).

The vast area previously occupied by both species during the LGM (Figs. 3a and 4a) appears have offered the appropriate environmental characteristics for the species to share haplotypes and may have served as potential refugia for tropical trees. This is likely the result of greater connectivity between populations and, consequently, more favorable conditions for the species to exchange alleles. Thus, the reduction in the suitable area over time may be responsible for the separation of these populations, although currently maintaining few haplotypes. A similar pattern as found by Carvalho et al. (2017) with an ENM analysis of the distribution and genetic diversity of Euterpe edulis species in the Brazilian Atlantic coast, indicating a reduction of climatically suitable areas over the time.

According to Behling and Hooghiemstra (2001), the Cerrado domain only became fully established after $7 \mathrm{kyr}$ BP. However, throughout the early Holocene, from 9.7 to $5.5 \mathrm{kyr}$ BP, the Cerrado was already reflecting a pattern of low precipitation and a dry season of 6 months, with the formation of some gallery forest. Furthermore, between 6 and $5 \mathrm{kyr} \mathrm{BP}$, the climate in most South American savannas was drier than during the late glacial and late Holocene periods, while distribution of the savanna (8.2 kyr BP) in the early Holocene was much wider than during the late Holocene (4.2 kyr BP) (Behling 2001). Similarly, our findings suggest that both species had experienced a reduction beginning in the last glacial period until current conditions, probably due to substantial forest reduction and expansion of the savannas during the midHolocene (5 kyr BP) (Ledru 1993).

Because it occurs on fertile soils, seasonally dry tropical forest areas have been widely converted to agricultural land use, which has resulted in the vast destruction of these forests in many Neotropical dry forest biomes (Murphy and Lugo 1995; Pennington et al. 2000). Additionally, global climate change may have a severe impact on the functioning, distribution, and establishment of species in ecosystems (Nabout et al. 2016). ENM has been widely used to predict the effects of climate change on species 

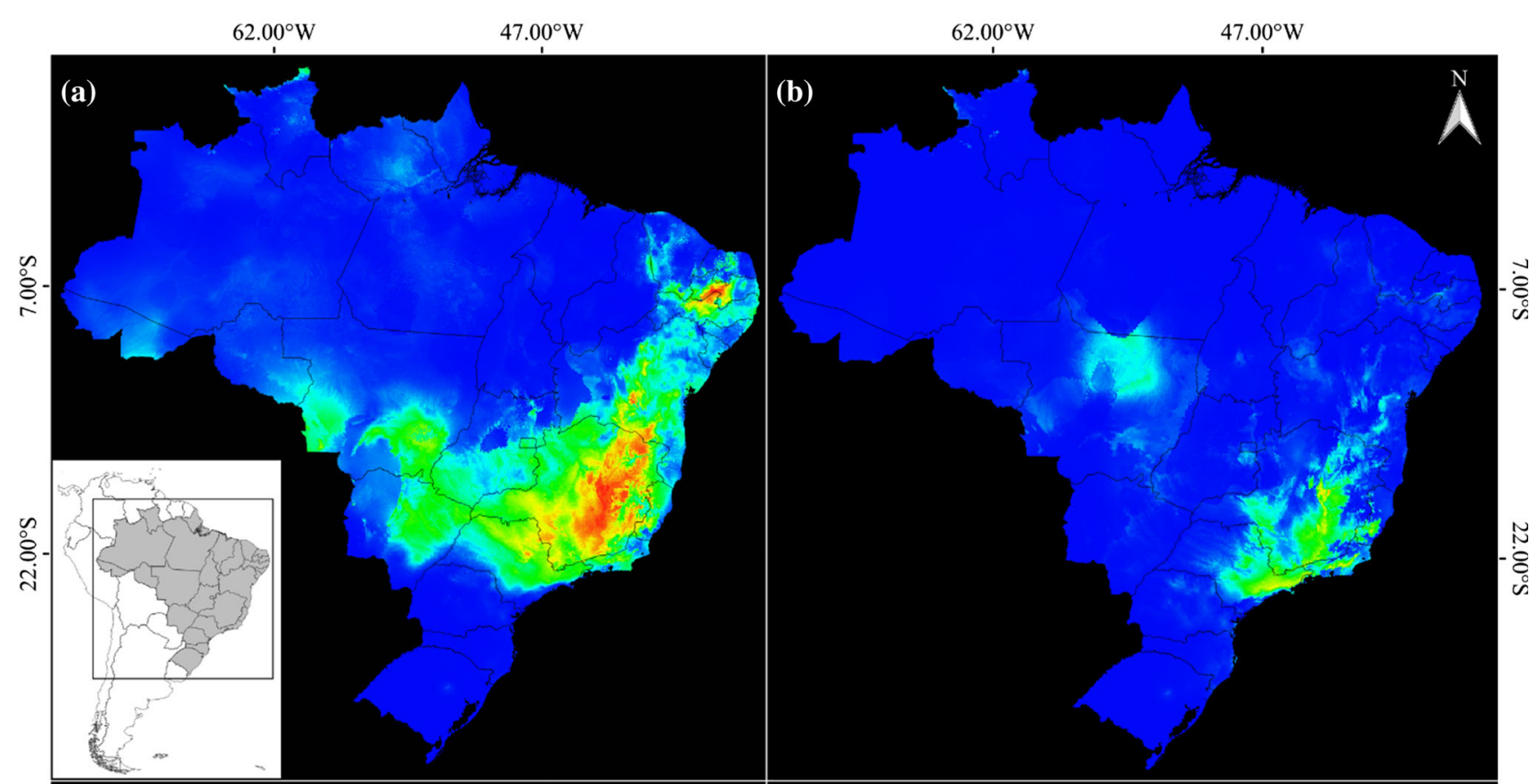

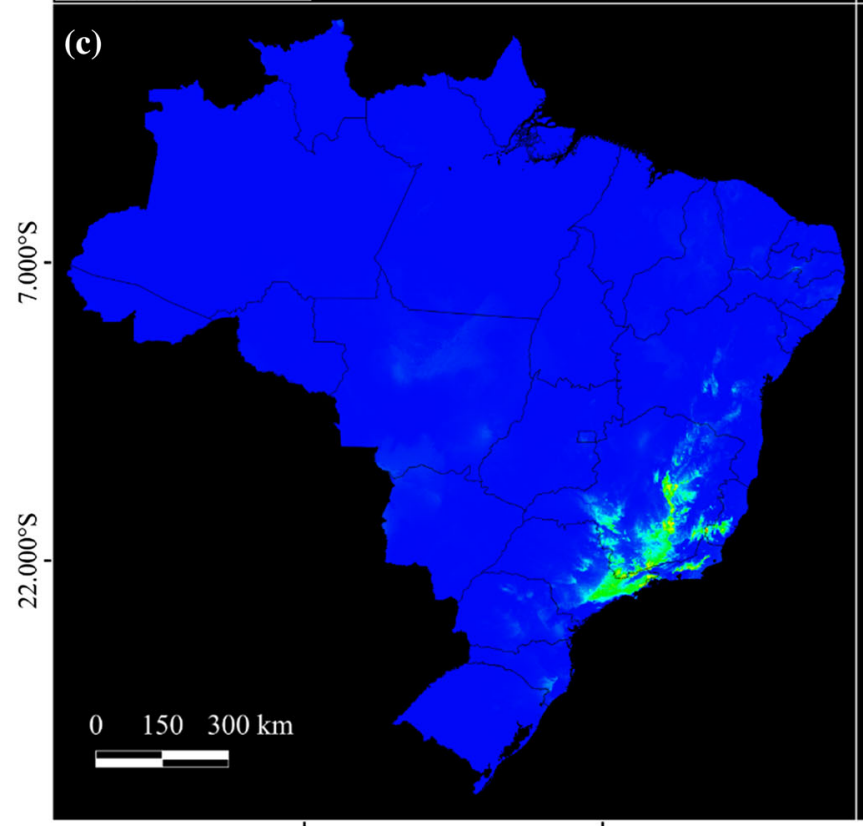

$62.000^{\circ} \mathrm{W}$

$47.000^{\circ} \mathrm{W}$

Fig. 3 Predictive ecological niche modeling (ENM) for Eremanthus erythropappus under four climatic scenarios: a last glacial maximum; b mid-holocene; c RCP 8.5 for 2070; and d RCP 2.6 for 2070. Red

distribution (Beck 2013; Peterson 2011). ENM for current and future projections showed a higher probability of occurrence for both species in the southern region of Minas Gerais State. This pattern can be the result of a reduction in suitable areas in the northern part of the state over time.

The current potential geographic distribution of E. erythropappus and E. incanus shows a wide distribution in the Cerrado and Caatinga biomes. However, our results indicate that the future climate change scenarios studied herein

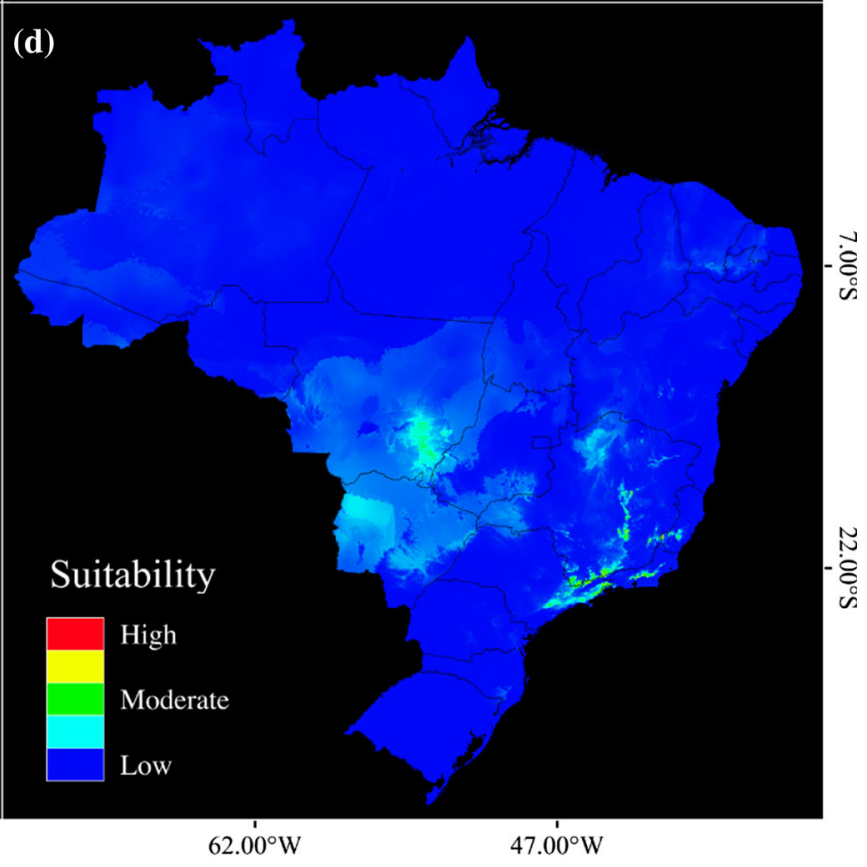

indicates regions with high probability of occurrence and blue indicates low probability of occurrence

will result in a significant reduction in the distribution of both studied species (Figs. 3c, d, 4c, d). Our study highlights the potential of bioclimatic variables to predict the effects of climate change for conservation purposes. We recommend the development of public policies that aim to include species genetic attributes in the maintenance of species viability. Such policies are necessary to ensure that both species studied herein will continue to reproduce and maintain diversity for future generations. Furthermore, the 


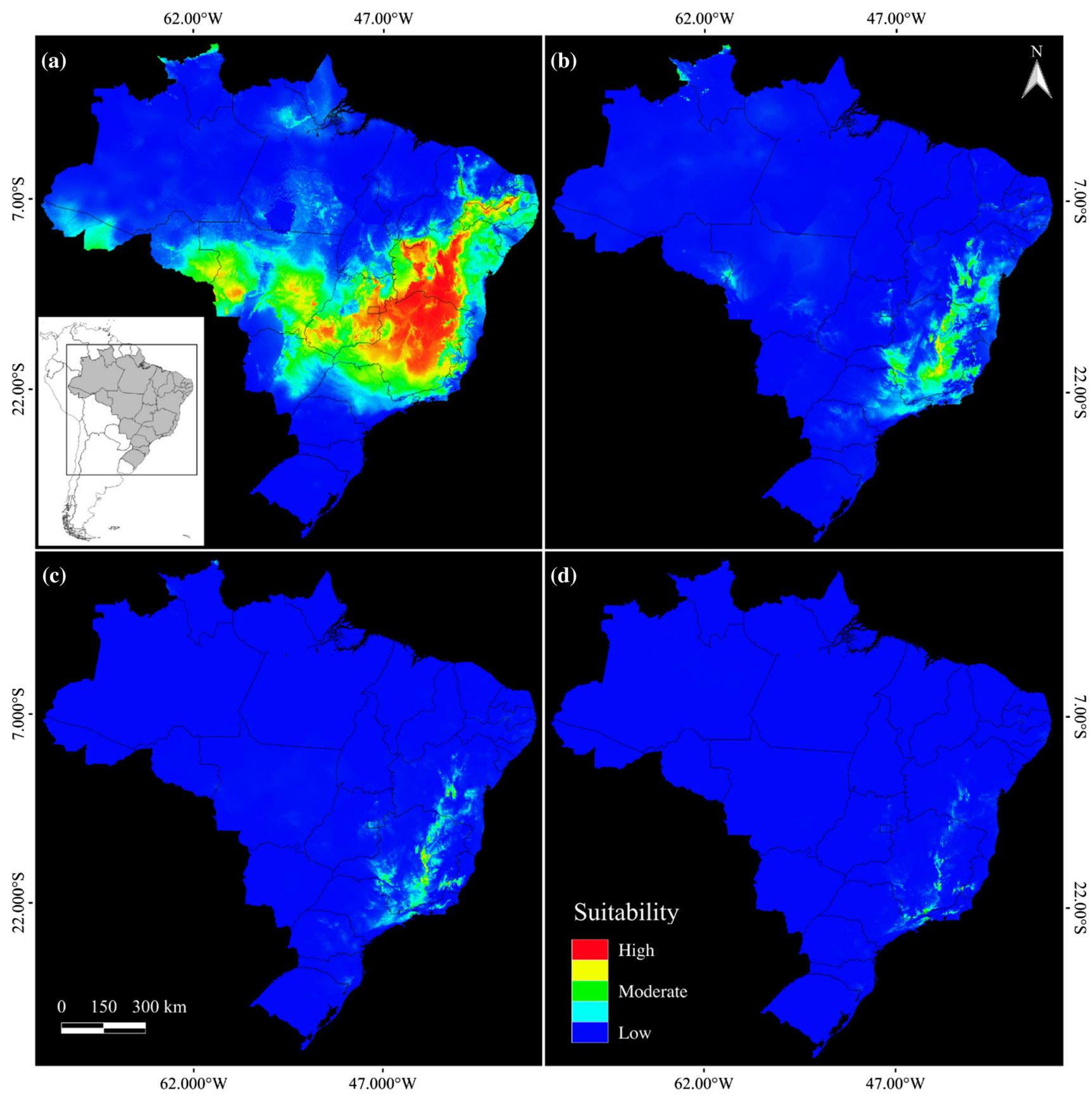

Fig. 4 Predictive ecological niche modeling (ENM) for Eremanthus incanus under four climatic scenarios: a last glacial maximum; b midHolocene; c RCP 8.5 for 2070; and d RCP 2.6 for 2070. Red indicates regions with high and blue indicates low probability of occurrence

genetic diversity of both species should be considered in the approval of new management plans to ensure their continuation into the future.

\section{Conclusion}

Priority areas for the conservation of E. erythropapus include the Medina population due to the presence of haplotype 1 and Franscisco Sá, Joaíma, and Rio Pardo de
Minas due to the occurrence of haplotype 2, which is exclusive to the northern region of Minas Gerais State. In the center-south region, the population of Lavras is also a priority because of the presence of haplotype 1, which differs from the other populations in the region. For $E$. incanus, it is necessary to preserve the populations of Franscisco Sá (north) and Lavras (center-south) as they present haplotype 3, and São Tomé das Letras because it is the only population to show haplotype 1 . 
The ecological niche modeling revealed an extensive area of occurrence of E. erythropappus and E. incanus during the last glacial maximum and also indicated a reduction in distribution following both the Mid-Holocene and current conditions. Additionally, the predictions for the year 2070 showed an even greater reduction in suitable area as a result of climate change.

Acknowledgements This study was financed in part by the Coordenação de Aperfeiçoamento de Pessoal de Nível Superior (CAPES)Finance code 001. We are thankful to the Conselho Nacional de Desenvolvimento Científico e Tecnológico (CNPq) and Fundação de Amparo à Pesquisa do Estado de Minas Gerais (FAPEMIG) for financial resources, and to Cristiano Rodrigues Reis for his help with the modeling.

Open Access This article is distributed under the terms of the Creative Commons Attribution 4.0 International License (http://crea tivecommons.org/licenses/by/4.0/), which permits unrestricted use, distribution, and reproduction in any medium, provided you give appropriate credit to the original author(s) and the source, provide a link to the Creative Commons license, and indicate if changes were made.

\section{References}

Abbott RJ, Brochmann C (2003) History and evolution of the arctic flora: in the footsteps of Eric Hulten. Mol Ecol 12:299-313

Abbott RJ, Comes HP (2004) Evolution in the Arctic: a phylogeographic analysis of the circumarctic plant, Saxifraga oppositifolia (Purple saxifrage). New Phytol 161:211-224

Araújo LC (1944) Vanillosmopsis erythropappa (DC.) Sch. Bip: sua exploração florestal. Dissertation, Escola Nacional de Agronomia, Seropédica

Avise JC (1994) Molecular markers, natural history, and evolution. Chapman \& Hall, New York

Avise J, Arnold J, Ball RM, Bermingham E, Lamb T, Neigel JE, Reeb CA, Saunders NC (1987) Intraspecific phylogeography: the mitochondrial DNA bridge between population genetics and systematics. Annu Rev Ecol Evol Syst 18:489-522

Barberi M, Salgado-Labouriau ML, Suguio K (2000) Paleovegetation and paleoclimate of "Vereda de Águas Emendadas", DF, Central Brazil. J South Am Earth Sci 13:241-254

Barreira S, Sebbenn AM, Scolforo JRS, Kageyama PY (2006) Diversidade genética e sistema de reprodução em população nativa de Eremanthus erythropappus (DC.) MacLeish sob exploração. Sci For 71:119-130

Beck J (2013) Predicting climate change effects on agriculture from ecological niche modeling: who profits, who loses? Clim Change 116:177-189

Behling H (2001) Late Quaternary environmental changes in the Lagoa da Curuça region (eastern Amazonia, Brazil) and evidence of Podocarpus in the Amazon lowland. Veg Hist Archaeobot 10:175-183

Behling H, Hooghiemstra H (2001) Neotropical savanna environments in space and time: late Quaternary interhemispheric comparisons. In: Interhemispheric climate linkages. Boulder, Colorado, pp 307-323

Birky CW, Walsh JB (1988) Effects of linkage on rates of molecular evolution. Proc Natl Acad Sci 85:6414-6418
Camolesi JF (2007) Volumetria e teor alfa-bisabolol para candeia Eremanthus erythropappus. Dissertation, Universidade Federal de Lavras

Carvalho CS, Ballesteros-Mejia L, Ribeiro MC, Côrtes MC, Santos AS, Collevatti RG (2017) Climatic stability and contemporary human impacts affect the genetic diversity and conservation status of a tropical palm in the Atlantic Forest of Brazil. Conserv Genet 18:467-478

CESM (2017) Community earth system model. http://www.cesm. ucar.edu/models/ccsm4.0/. Accessed 12 Apr 2017

Chen JM, Zhao SY, Liao YY, Gichira AW, Gituru RW, Wang QF (2015) Chloroplast DNA phylogeographic analysis reveals significant spatial genetic structure of the relictual tree Davidia involucrata (Davidiaceae). Conserv Genet 16:583-593

Cloutier D, Povoa JS, Procopio LC, Leao NV, Wadt LD, Ciampi AY, Schoen DJ (2005) Chloroplast DNA variation of Carapa guianensis in the Amazon basin. Silvae Genet 54(1-6):270-274

Collevatti RG, Terribile LC, Lima-Ribeiro MS, Nabout JC, Oliveira G, Rangel TF, Rabelo SG, Diniz-Filho JA (2012) A coupled phylogeographical and species distribution modelling approach recovers the demographical history of a neotropical seasonally dry forest tree species. Mol Ecol 21:5845-5863

Collevatti RG, Terribile LC, Oliveira G, Lima-Ribeiro MS, Nabout JC, Rangel TF, DinizFilho JA (2013) Drawbacks to palaeodistribution modelling: the case of South American seasonally dry forests. J Biogeogr 40:345-358

Collevatti RG, Terribile LC, Rabelo SG, Lima-Ribeiro MS (2015) Relaxed random walk model coupled with ecological niche modelling unravel the dispersal dynamics of a neotropical savannah tree species in the deeper Quaternary. Front Plant Sci 6:653

Comes HP, Kadereit JW (1998) The effect of Quaternary climatic changes on plant distribution and evolution. Trends Plant Sci $11: 432-438$

De-Granville JJ (1988) Phytogeographical characteristics of the Guianan forests. Taxon 1:578-594

Demesure B, Sodzi N, Petit RJ (1995) A set of universal primers for amplification of polymorphic non-coding regions of mitochondrial and chloroplast DNA in plants. Mol Ecol 4:129-134

Dumolin-Lapegue S, Pemonge MH, Petit RJ (1997) An enlarged set of consensus primers for the study of organelle DNA in plants. Mol Ecol 6:393-397

Elith J, Graham CH, Anderson RP, Dudík M, Ferrier S, Guisan A, Hijmans RJ, Huettmann F, Leathwick JR, Lehmann A, Li J (2006) Novel methods improve prediction of species' distributions from occurrence data. Ecography 1:129-151

Estopa RA, Souza AD, Moura MC, Botrel MC, Mendonça EG, Carvalho D (2006) Diversidade genética em populações naturais de candeia (Eremanthus erythropappus (DC.) MacLeish). Sci For 70:97-106

Excoffier L, Smouse PE (1994) Using allele frequencies and geographic subdivision to reconstruct gene trees within a species: molecular variance parsimony. Genetics 136:343-359

Excoffier L, Laval G, Schineider SL (2007) Arlequin versión 3.11: a sofware for population genetic data analysis. University of Geneva, Geneva

Fielding AH, Bell JF (1997) A review of methods for the assessment of prediction errors in conservation presence/absence models. Environ Conserv 24:38-49

GBIF (2018) Global biodiversity information facility: Free and open access to biodiversity data. https://www.gbif.org. Accessed 22 Aug 2018

Gent PR (2011) The community climate system model version 4 . J Clim 24:4973-4991

Gries R, Louzada J, Almeida S, Macedo R, Barlow J (2012) Evaluating the impacts and conservation value of exotic and 
native tree afforestation in Cerrado grasslands using dung beetles. Insect Conserv Diver 5:175-185

Hamilton MB (1999) Four primer pairs for the amplification of chloroplast intergenic regions with intraspecific variation. Mol Ecol 8:513-525

Hernandez PA, Graham CH, Master LL, Albert DL (2006) The effect of sample size and species characteristics on performance of different species distribution modeling methods. Ecography 29:773-785

Hewitt G (2000) The genetic legacy of the quaternary ice ages. Nature 405:907

Hijmans RJ, Cameron SE, Parra JL, Jones PG, Jarvis A (2005) Very high resolution interpolated climate surfaces for global land areas. Int J Climatol 25:1965-1978

Iganci JR, Heiden G, Miotto ST, Pennington RT (2011) Campos de Cima da Serra: the Brazilian subtropical highland grasslands show an unexpected level of plant endemism. Bot J Linn Soc 167:378-393

Kremer A, Ronce O, Robledo-Arnuncio JJ, Guillaume F, Bohrer G, Nathan R, Bridle JR, Gomulkiewicz R, Klein EK, Ritland K, Kuparinen A (2012) Long distance gene flow and adaptation of forest trees to rapid climate change. Ecol Lett 15:378-392

Ledru MP (1993) Late quaternary environmental and climatic changes in central Brazil. Quat Res 39:90-98

Lexer A, Widmer C (2001) Glacial refugia: sanctuaries for allelic richness, but not for gene diversity. Trends Ecol Evol $16: 267-268$

Lima JS, Ballesteros-Mejia L, Lima-Ribeiro MS, Collevatti RG (2017) Climatic changes can drive the loss of genetic diversity in a Neotropical savanna tree species. Global Change Biol 23:4639-4650

Loeuille B, Lopes JC, Pirani JR (2012) Taxonomic novelties in Eremanthus (Compositae: vernonieae) from Brazil. Kew Bull 67:1-9

Lorenzi H (1992) Árvores brasileiras: manual de identificação e cultivo de plantas arbóreas nativas do Brasil. Plantarum, Nova Odessa

MacLeish ANFF (1987) Revision of Eremanthus (Compositae: vernonieae). Ann Missouri Bot Gard 74:265-290

Mayle FE, Burn MJ, Power M, Urrego DH (2009) Vegetation and fire at the last glacial maximum in tropical South America. In: Vimeux F, Sylvestre F, Khodri M (eds) Past climate variability from the last glacial maximum to the holocene in South America and surrounding regions. Springer, Berlin, pp 89-112

Miranda NA, Titon M, Pereira IM, Fernandes JSC, Gonçalves JF, Rocha FM (2016) Culture medium, growth regulators and ways of sealing test tubes on in vitro multiplication of candeia (Eremanthus incanus (Less.) Less). Sci Flor 44:1009-1018

Moura MCO (2005) Distribuição da variabilidade genética em populações naturais de Eremanthus erythropappus (DC.) MacLeish por isoenzimas e RAPD. D. Phil. Thesis. Universidade Federal de Lavras

Murphy PG, Lugo AE (1995) Dry forests of central America and the Caribbean. In: Bullock SH, Mooney HA, Medina E (eds) Seasonally dry tropical forests. Cambridge University Press, Cambridge, pp 9-34

Myers N, Mittermeier RA, Mittermeier CG, da Fonseca GAB, Kent J (2000) Biodiversity hotspots for conservation priorities. Nature 403:853-858

Nabout JC, Magalhães MR, de Amorim Gomes MA, Da Cunha HF (2016) The impact of global climate change on the geographic distribution and sustainable harvest of Hancornia speciosa (Apocynaceae) in Brazil. Environ Manag 57:814-821

Nei M, Maruyama T, Chakraborty R (1975) The bottleneck effect and genetic variability in populations. Evolution 29:1-10
Newton AC, Allnutt TR, Gillies AC, Lowe AJ, Ennos RA (1999) Molecular phylogeography, intraspecific variation and the conservation of tree species. Trends Ecol Evol 14:140-145

Pádua JA, Brandão MM, de Carvalho D (2016) Spatial genetic structure in natural populations of the overexploited tree Eremanthus erythropappus (DC.) macleish (Asteraceae). Biochem Syst Ecol 66:307-311

Pennington TR, Prado DE, Pendry CA (2000) Neotropical seasonally dry forests and Quaternary vegetation changes. J Biogeogr 27:261-273

Peterson AT (2011) Ecological niche conservatism: a time-structured review of evidence. J Biogeogr 38:817-827

Petit RJ, El Mousadik A, Pons O (1998) Identifying populations for conservation on the basis of genetic markers. Conserv Biol 24:844-855

Phillips SJ (2017) A brief tutorial on maxent. http://biodiversityinfor matics.amnh.org/open_source/maxent/. Accessed 13 Mar 2017

Phillips SJ, Dudík M (2008) Modeling of species distributions with Maxent: new extensions and a comprehensive evaluation. Ecography 31:161-175

Pons O, Petit RJ (1996) Measuring and testing genetic differentiation with ordered versus unordered alleles. Genetics 144:1237-1245

Prado DE, Gibbs PE (1993) Patterns of species distributions in the dry seasonal forests of South America. Ann Missouri Bot Gard 1:902-927

Prance GT (1973) Phytogeographic support to the theory of Pleistocene forest refuges in the Amazon Basin, based on evidence from distribution patterns in Caryocaraceae, Chrysobalanaceae, Dichapetalaceae and Lecythidaceae. Acta Amaz 3:5-26

Prance GT (1982) Biological diversification in the tropics. Columbia University, New York

Provan J, Soranzo N, Wilson NJ, Goldstein DB, Powell W (1999) A low mutation rate for chloroplast microsatellites. Genetics 153:943-947

Ravenscroft CH, Whitlock R, Fridley JD (2015) Rapid genetic divergence in response to 15 years of simulated climate change. Global Change Biol 21:4165-4176

Rawat A, Barthwal S, Ginwal HS (2014) Comparative assessment of SSR, ISSR and AFLP markers for characterization of selected genotypes of Himalayan Chir pine (Pinus roxburghii Sarg.) based on resin yield. Silvae Genet 63:94-108

Schlögl PS, Souza AP, Nodari RO (2007) PCR-RFLP analysis of noncoding regions of cpDNA in Araucaria angustifolia (Bert.) O. Kuntze. Genet Mol Biol 30:423-427

Scolforo JRS, Oliveira AD, Davide AC (2012) O manejo sustentável da candeia: o caminhar de uma nova experiência florestal em Minas Gerais. Editora UFLA, Lavras

Silva AC, Rosado SCS, Vieira CT, Carvalho D (2007) Variação genética entre e dentro de populações de candeia (Eremanthus erythropappus (DC.) MacLeish). Ci. Fl. 17:271-277

Stocker TF, Qin D, Plattner GK, Tignor M, Allen SK, Boschung J, Nauels A, Xia Y, Bex V, Midgley PM. IPCC (2013) Climate change 2013: the physical science basis. Contribution of working group I to the fifth assessment report of the intergovernmental panel on climate change, Cambridge University Press. Cambridge

Taberlet P, Gielly L, Pautou G, Bouvet J (1991) Universal primers for amplification of three non-coding regions of chloroplast DNA. Plant Mol Biol 17:1105-1109

Tse-ring, K, Sharma, E, Chettri, N, Shrestha, AB (2010). Climate change vulnerability of mountain ecosystems in the Eastern Himalayas. International centre for integrated mountain development (ICIMOD). http://lib.riskreductionafrica.org/bitstream/ handle/123456789/485/climate\%20change\%20vulnerability\% 
20 of $\% 20$ mountain $\% 20$ ecosystems $\% 20$ in $\% 20$ the $\% 20$ East ern\%20Himalayas.pdf?sequence=1. Accessed 15 Apr 2017

Vieira FDA, Fajardo CG, Carvalho D (2012) Biologia floral de candeia (Eremanthus erythropappus, Asteraceae). Pesqui Florest Bras 32:477

Vieira FDA, Novaes RML, Fajardo CG, Santos RMD, Almeida HDS, Carvalho D, Lovat MB (2015) Holocene southward expansion in seasonally dry tropical forests in South America: phylogeography of Ficus bonijesulapensis (Moraceae). Bot J Linn Soc 177:189-201
Wisz MS, Hijmans RJ, Li J, Peterson AT, Graham CH, Guisan A (2008) Effects of sample size on the performance of species distribution models. Divers Distrib 14:763-773

Zuber SM, Villamil MB (2016) Meta-analysis approach to assess effect of tillage on microbial biomass and enzyme activities. Soil Biol Biochem 30:176-187

Publisher's Note Springer Nature remains neutral with regard to jurisdictional claims in published maps and institutional affiliations. 